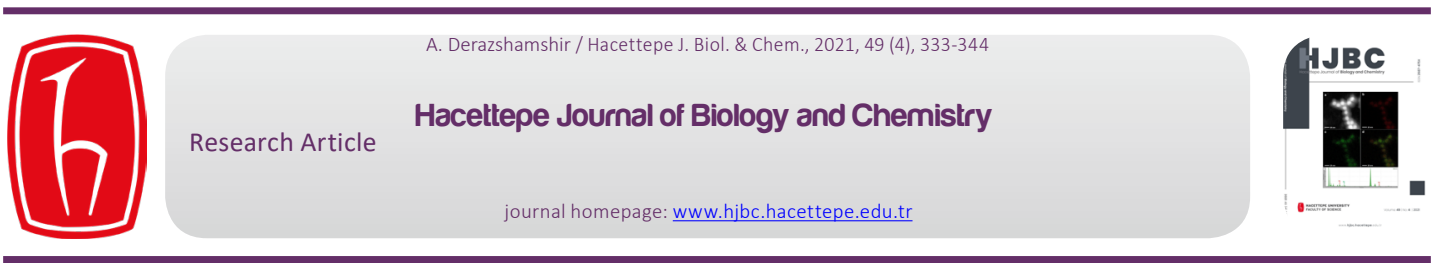

\title{
Preparation of Molecularly Imprinted Optical Sensors for the Real Time Detection of Phenol
}

\section{Fenolün Gerçek Zamanlı Tayini için Moleküler Baskılanmış Optik Sensörlerin Hazırlanması}

\section{Ali Derazshamshir}

Hacettepe University, Department of Chemistry, Beytepe, Ankara, Turkey.

\section{ABSTRACT}

$\mathrm{n}$ recent years, it has become important to identify phenols and their compounds that pose an important threat to living things and public health. In this study, phenol imprinted surface plasmon resonance (SPR) sensors were designed based on molecular imprinted method for detection of phenol. Polymeric film with cavities of phenol molecules was prepared and formed on the SPR chip surface by UV polymerization. The limit of detection range from 0.15 to $10 \mathrm{nM}$ was $0.022 \mathrm{nM}$. Furthermore, we performed the selectivity experiments, where catechol was chosen as competitor agent. Overall, phenol imprinted SPR sensor prepared by the molecular imprinting approach has been found to be highly sensitive and selective for phenol. Phenol imprinted SPR sensors are considered to be used as a new method for existing phenol determination methods with their high selectivity, repetitive use and fast responses.

\section{Key Words}

Phenol, molecular imprinting, sensor, surface plasmon resonance.

\section{ÖZ}

\begin{abstract}
on yıllarda, canlılar ve halk sağlığı için önemli bir tehdit oluşturan fenol ve bileşiklerinin tespit edilmesi önem kazanmak tadır. Bu çalışmada, fenolün tespiti için moleküler baskılama yöntemi temel alınarak fenol baskılanmış yüzey plazmon rezonans (SPR) sensörler tasarlanmıştır. Fenol moleküllerine ait boşluklara sahip polimerik film hazırlanarak UV polimerizasyonu ile SPR sensör yüzeyinde oluşturulmuştur. 0.15 ile $10 \mathrm{nM}$ arasındaki tayin aralığında en düşük saptama sınırı 0.022 nM'dir. Ayrıca, seçicilik katekolün yarışmacı ajan olarak seçilmiş ve seçicilik deneylerini gerçekleştirilmiştir. Genel olarak, moleküler baskılama yaklaşımı ile hazırlanan fenol baskılanmış SPR sensörünün fenol için oldukça hassas ve seçici olduğu bulunmuştur. Fenol baskılı SPR sensörleri, yüksek seçicilikleri, tekrar kullanılabilirliliği ve hızı yanıtları özelliği ile mevcut fenol belirleme yöntemlerine alternatif yeni bir yöntem olarak kullanılmak düşünülmektedir.
\end{abstract}

\section{Anahtar Kelimeler}

Fenol, moleküler baskılama, sensör, yüzey plazmon rezonansı.

Article History: Received: Apr 5, 2021; Revised: May 15, 2021; Accepted: May 15, 2021; Available Online: June 5, 2021.

DOI: https://doi.org/10.15671/hjbc.922633

Correspondence to: A. Derazshamshir, Hacettepe University, Department of Chemistry, Beytepe, Ankara, Turkey.

E-Mail: aliderazshamshir@gmail.com 


\section{INTRODUCTION}

urface plasmon resonance (SPR) sensors are a simple $S$ and direct measurement technique and depends on measuring the change in the refractive index adjacent to the metal surface. In the surface plasmon resonance method, a thin metal film is used between two permeable and different refractive index media [1-3]. When light enters a much less dense transparent media, it does not transition and is diffracted in the dense media (glass prism). Surface plasmon resonance (SPR) sensors are obtained by creating regions on the metal surface that will allow biorecognition [4-6]. When the solution containing the template molecule interacts with SPR sensor, the target molecule attaches to the sensor surface and causes increased surface density. The increase in density on the surface leads the refractive index of the surface to increase. This increase in refractive index results in shifting of the resonance angle $[7,8]$.

The presence of phenol in the aquatic environment causes the death of aquatic organisms and results poor water quality. Therefore, phenol can cause weight loss, diarrhea, dizziness, loss of appetite and irritation in the digestive system as the effects of chronic exposure [914]. It also causes damage to the liver, causing changes in blood pressure and adverse effects on the nervous system. According to researches, developmental retardation and weight loss have also been observed in animals exposed to phenol [15-18]. Phenol and its derivatives such as methylphenol, chlorophenol and nitrophenol are highly toxic contaminants. There are many reliable methods for determining these pollutants. However, the disadvantage of these methods is that they require complicated procedures for sample pretreatment [19-28].

In this study, phenol imprinted and non-imprinted SPR sensors were prepared for the determination of phenol compound by using the advantages of molecular imprinting method. Molecular imprinting method is a new technology that spreads the production of smart polymers and their use in different applications in order to separate biomolecules, ions and organic molecules from different matrices [29-32]. In molecular imprinting, atoms, ions, molecules, complexes or micro-organisms can be used as templates. In recent years, the preparation, characterization and continuous development of molecular imprinted polymers have attracted considerable amount of attention in the literature [33-39].
Phenol imprinted poly(2-hydroxyethyl methacrylate$\mathrm{N}$-methacryloyl-(L)-phenylalanine methyl ester) [poly(HEMA-MAPA)] polymeric film was attached to on the SPR chip gold surfaces. Phenol imprinted and nonimprinted SPR chip surfaces were characterized by several techniques such as, ellipsometer and contact angle measurements. Binding kinetics and detection dynamics of phenol molecules were examined by binding the phenol at different concentrations applied to the phenol imprinted SPR sensors. The selectivity and reusability studies, which is the most important feature of molecular imprinted SPR sensors, were realized in this study. Phenol imprinted polymeric films were found to show more sensitivity towards the target molecule than the non-imprinted ones.

\section{MATERIALS and METHODS}

\section{Chemicals}

2,2'-Azobis(2-methylpropionitrile), sodium hydroxide, 2-hydroxyethyl methacrylate, hydrochloric acid, ethylene glycol dimethacrylate and allyl mercaptan to be used for synthesis of SPR chip were purchased from Merck (Switzerland). Phenol and Catechol were purchased from Merck (Switzerland).

\section{Synthesis of polymeric film on SPR chip surfaces}

The surface modification was performed on the SPR chip surface with allyl mercaptan for $12 \mathrm{~h}$. Synthesis procedure of $\mathrm{N}$-methacryloyl-(L)-phenylalanine methyl ester (MAPA) used as monomer was explained by Denizli et al. in the previous articles [40]. In this study, MAPA was used as monomer for phenol imprinted polymeric film synthesis. Both the template molecule phenol and the MAPA monomer have a hydrophobic structure. Phenol is a structure in which the $\mathrm{OH}$ - molecule is attached to the benzene ring. The MAPA monomer also has a benzene ring in the same way as phenol. The electrostatic and hydrophobic interactions take place between similar rings of two molecules [41]. For the synthesis of phenol imprinted polymeric film, the precomplex consisted of 1:5 $\mu \mathrm{M}$ for phenol:MAPA was formed with the template molecule as phenol $(10 \mu \mathrm{mol})$ and monomer as MAPA (50 $\mu \mathrm{mol})$. Phenol imprinted polymeric film (MIP) was prepared with phenol:MAPA pre-complex with ethylene glycol dimethacrylate (EGDMA, $200 \mu \mathrm{mol}$ ) as a crosslinker, 2-hydroxyethylmethacrylate (HEMA, $50 \mu \mathrm{mol})$ as a functional monomer and 
2,2-azobisisobutyronitrile (AIBN) as a polymer initiator $5 \mu \mathrm{L}$ of this mixture is dropped on the SPR chip surface and placed under UV light in $24^{\circ} \mathrm{C}$ at $40 \mathrm{~min}$. The nonimprinted (NIP) polymeric film was prepared using the same procedure without adding phenol into the polymer solution.

\section{Characterization studies}

The characterization studies of phenol imprinted and non-imprinted SPR chip surfaces were carried out with ellipsometer and contact angle (CA) measurements. An automatic nulling imaging ellipsometer (Nanofilm EP3, Germany) was used in layer thickness of the polymeric film on the SPR chip surface. Contact angle measurements of SPR chip surfaces were measured with sessile drop method using KRUSS DSA100 (Hamburg, Germany) device [42].

\section{Kinetic studies}

The detection of phenol from the aqueous solution, kinetic analyzes performed using phenol imprinted and non-imprinted SPR sensors. Firstly, phenol imprinted sensor was equilibrated with $\mathrm{pH} 6.5$ phosphate buffer solution [43]. Phenol solutions in different concentration of 0.15-10.0 nM was prepared and kinetic analyzes were performed in the SPRimager II (USA) sensor system (10 mL, $120 \mu \mathrm{L} / \mathrm{min}$ ). Refractive index values were obtained by taking SPR sensorgrams. After all kinetic analysis, the phenol molecules were removed from the cavities on the SPR chip surface using $0.5 \mathrm{M}$ $\mathrm{NaCl}$ desorption solution. Using kinetic data, adsorption isotherm models and equilibrium kinetic analysis were calculated for phenol imprinted SPR sensors [44].

$$
\begin{array}{ll}
\Delta R=\left\{\Delta R_{\max }[C]^{1 / n} / K_{D}+[C]^{1 / n}\right\} & \text { Eq.1: Langmuir-Freundlich } \\
\Delta R=\Delta R_{\max }[C]^{1 / n} & \text { Eq.2: Freundlich } \\
\Delta R=\left\{\Delta R_{\max }[C] / K_{D}+[C]\right\} & \text { Eq.3: Langmuir } \\
d \Delta R / d_{t}=k_{a} C \Delta R_{\max }-\left(k_{a} C+k_{d}\right) \Delta R & \text { Eq.4: Eq. kinetic alysis } \\
\Delta R_{e x} / C=K_{A}\left(\Delta R_{\max }-\Delta R_{e q}\right) & \text { Eq.5: Scatchard }
\end{array}
$$

Concentration, the response measured by binding, and the Freundlich exponent is expressed with $C, \Delta R$ and $1 / n$, respectively. The forward kinetic rate constant is $k_{a}$ $(1 / n M . s)$ and reverse kinetic rate constant is $k_{d}(1 / s)$. The forward equilibrium constant is $\mathrm{K}_{\mathrm{A}}\left(\mathrm{nM}^{-1}\right)$ and reverse equilibrium constant is $K_{D}(n M)$.
To determine the selectivity of the phenol imprinted and non-imprinted SPR sensors, catechol used as competitive molecule. The molecular weight and structure of catechol $\left(\mathrm{C}_{6} \mathrm{H}_{6} \mathrm{O}_{2}, \mathrm{MW}: 110.112 \mathrm{~g} / \mathrm{mol}\right)$ molecule is close to phenol $\left(\mathrm{C}_{6} \mathrm{H}_{6} \mathrm{O}, \mathrm{MW}: 94.11 \mathrm{~g} / \mathrm{mol}\right)$. Catechol solution at a concentration of $5 \mathrm{nM}$ was prepared and kinetic analyzes were performed with phenol imprinted and non-imprinted SPR sensors. The selectivity ( $k$ ) and the relative selectivity $\left(k^{\prime}\right)$ coefficients were calculated using the obtained kinetic data [45].

$$
\begin{array}{ll}
k=\Delta R_{\text {template }} / \Delta R_{\text {competitor }} & \begin{array}{l}
\text { Eq.6: The selectivity coef- } \\
\text { ficient }
\end{array} \\
k^{\prime}=k_{\text {imprinted }} / k_{\text {non-imprinted }} & \begin{array}{l}
\text { Eq.7: The relative selectivity } \\
\text { coefficient }
\end{array}
\end{array}
$$

\section{Experimental results \\ Characterization of SPR chip surfaces}

The characterization studies of phenol imprinted and non-imprinted SPR chip surfaces were done using ellipsometer and contact angle measurements. The polymeric film thickness of the SPR chip surfaces were determined by ellipsometer measurements. The polymeric film thicknesses of phenol imprinted and nonimprinted SPR were obtained as $109.5 \pm 0.7 \mathrm{~nm}$ and $132.5 \pm 0.2 \mathrm{~nm}$, respectively (Figure 1 ).

Contact angle (CA) measurements of unmodified and phenol imprinted SPR chip surfaces were shown in $\mathrm{Fi}$ gure $2 \mathrm{~A}$ and $2 \mathrm{~B}$. After preparation of phenol imprinted polymeric film on the SPR chip surface, the CA value increased from $71.4^{\circ}$ to $92.3^{\circ}$. The observed increase in contact angles depended on the increase of hydrophobic of SPR chip surfaces. The increase of hydrophobic property of SPR chip surface is expected due to the hydrophobic functional groups of MAPA monomer [46].

\section{The real time kinetic analysis}

Phenol imprinted and non-imprinted SPR sensors were prepared by molecular imprinting approach for detection of phenol. Phenol imprinted SPR sensor was analyzed with phenol aqueous solutions in the concentration range from 0.15 to $10 \mathrm{nM}$. Firstly, phenol imprinted SPR sensor was equilibrated with $\mathrm{pH} 6.5$ phosphate buffer. Then, phenol aqueous solutions prepared at a concentration of 0.15 to $10 \mathrm{nM}$ were given to the SPR system one by one and the refractive index $(\% \Delta R)$ values were obtained in Figure 3. The desorption studies from SPR chip surface were performed using $0.5 \mathrm{M} \mathrm{NaCl}$ solution. 

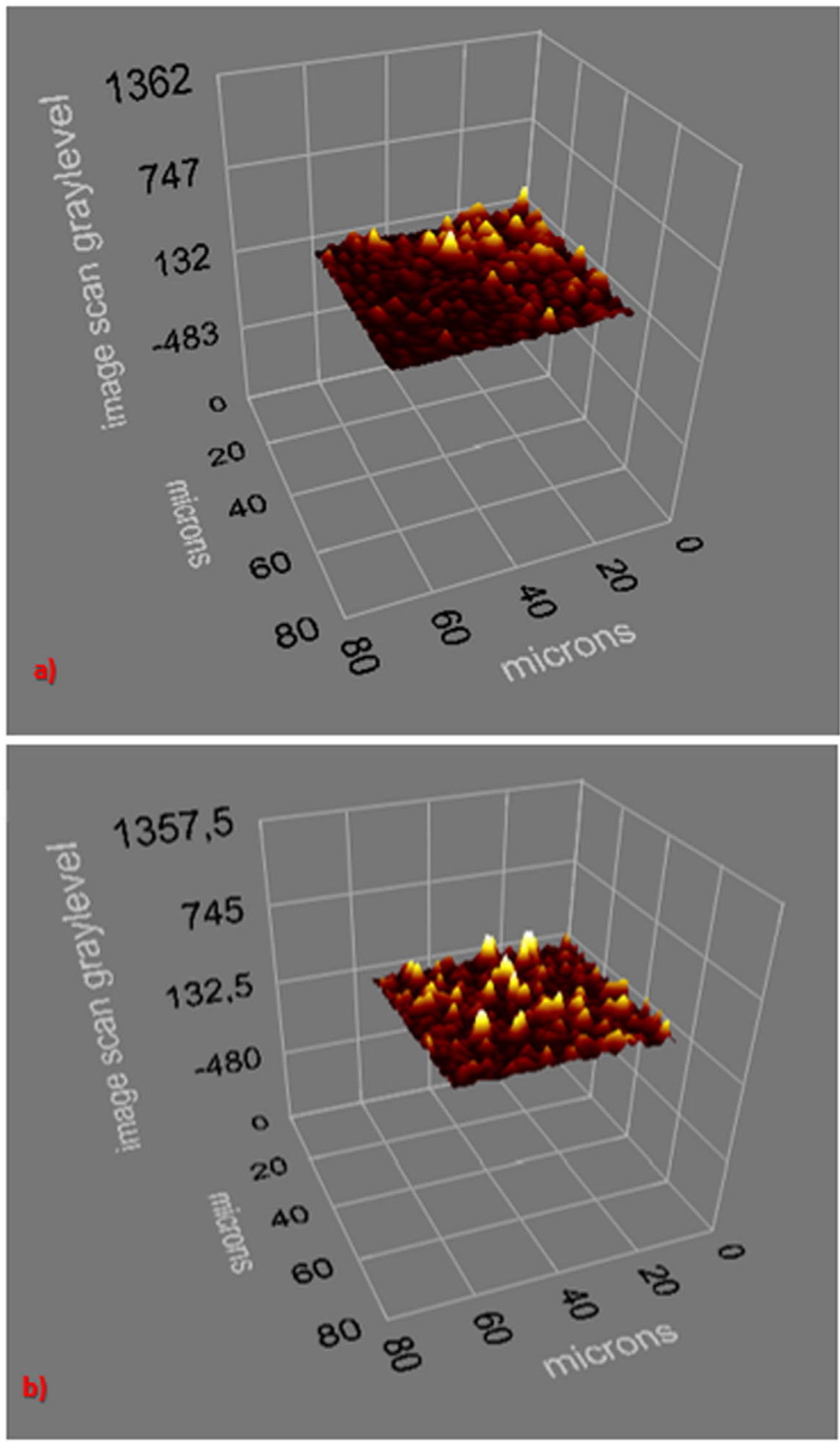

Figure 1. Ellipsometer images (a: phenol imprinted and b: non-imprinted SPR chip surface). 


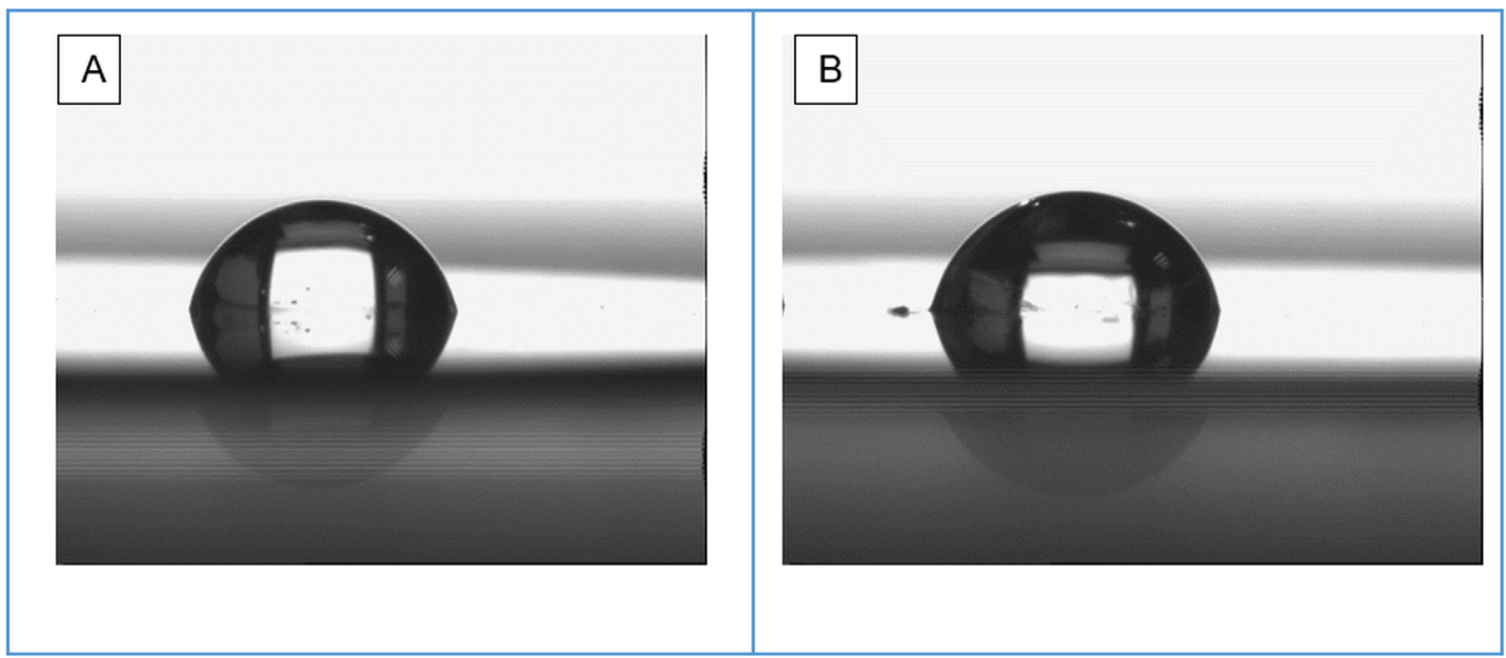

Figure 2. Contact angle images (A: unmodified and B: phenol imprinted SPR chip surfaces).

As seen in Figure 4, an increase in phenol imprinted SPR sensor response is observed with the increase in phenol concentration. There is a direct relationship between solutions of different phenol concentrations and\% $\Delta \mathrm{R}$ as the reflection response. In this study, the linear equation is $y=1.3103 x+2.4997$ with a coefficient of 0.9095 . Using the kinetic data of phenol imprinted SPR sensor, the limit of detection $(\mathrm{LOD}=3.3 \mathrm{~S} / \mathrm{m})$ was determined to be $0.022 \mathrm{nM}$.
The equilibrium and kinetic analysis constants for phenol imprinted SPR sensor are calculated and given in Table 1. The association constant $\left(\mathrm{K}_{A}\right)$ value was showed the high affinity binding for phenol to be $2.36 \mathrm{nM}^{-1}$ for kinetic studies. The heterogeneity of the SPR chip surface and its affinity for the binding sites of phenol molecules can be explained by the Scatchard model curve. The $\mathrm{K}_{\mathrm{A}}$ value was calculated to be $0.18 \mathrm{nM}^{-1}$ for phenol recognition.

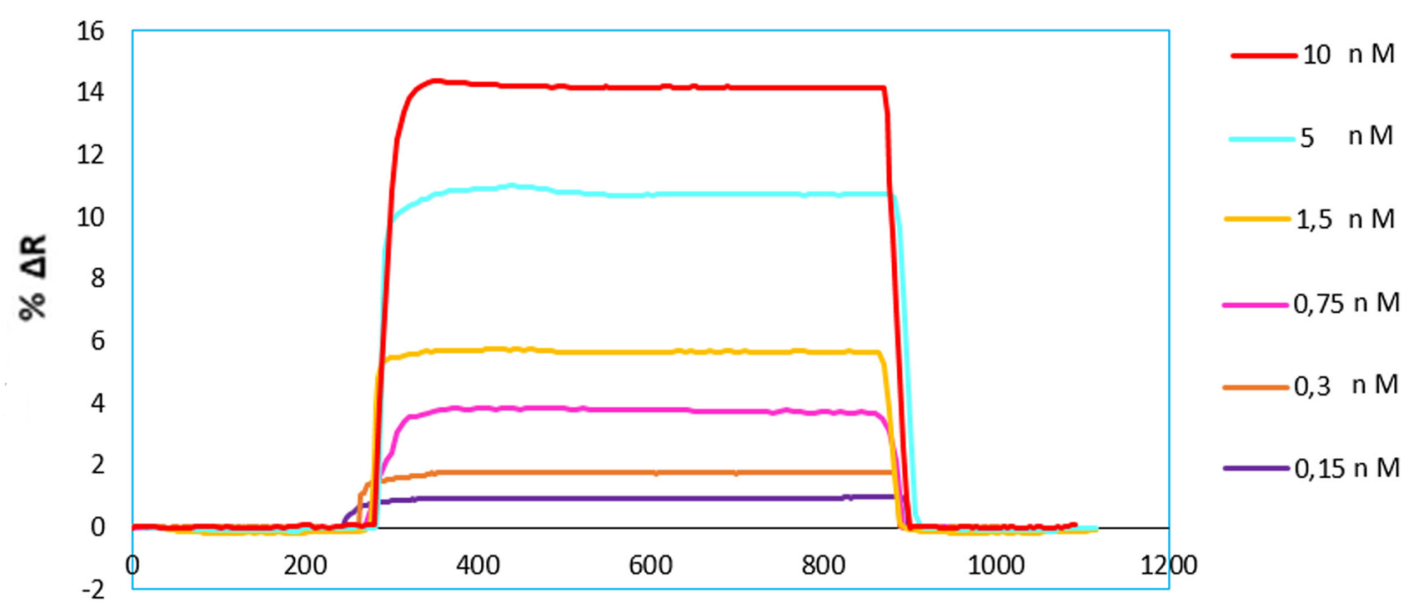

Time, Sec.

Figure 3. Real-time responses of phenol imprinted SPR sensor. 


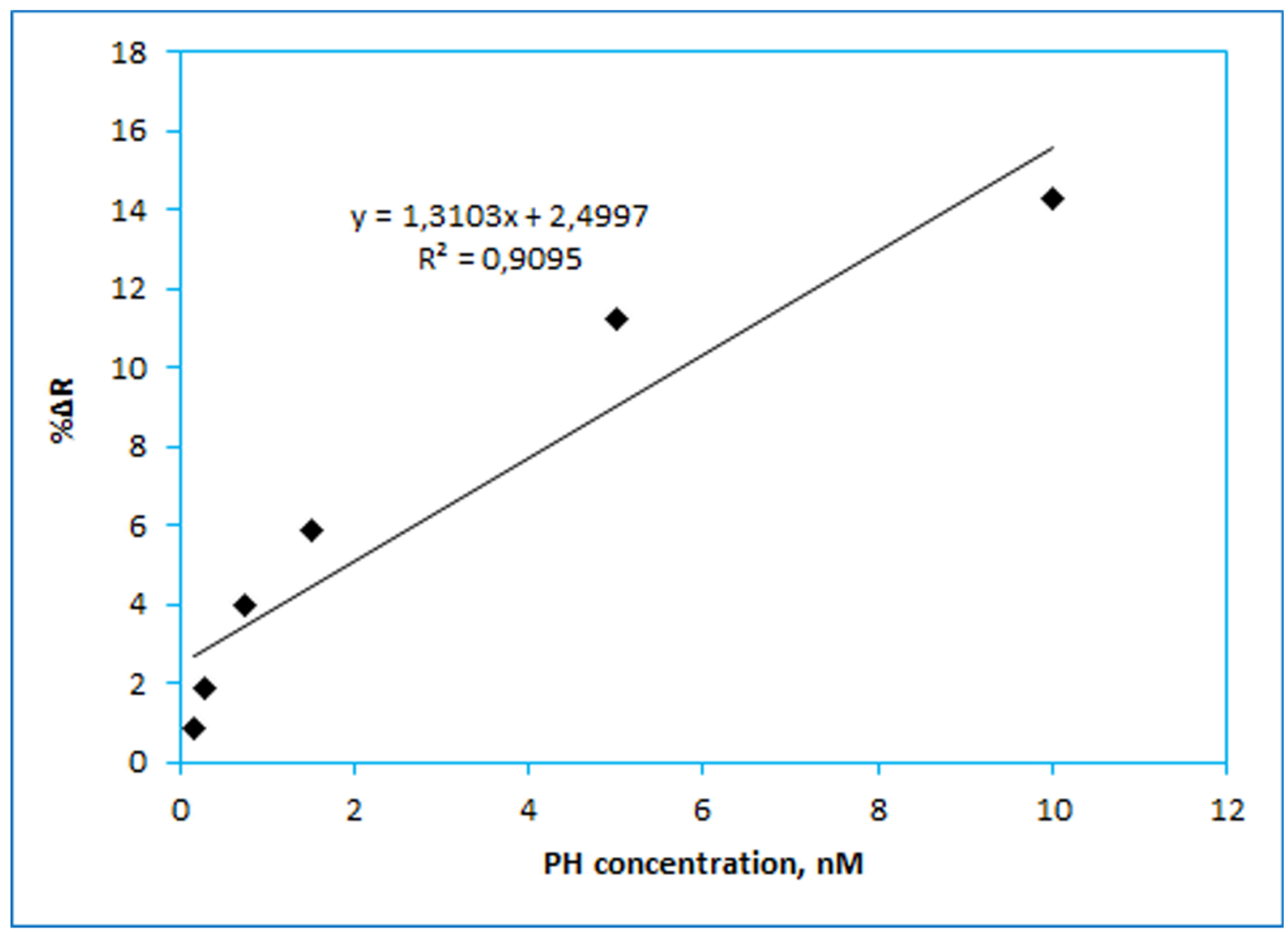

Figure 4. The linearity of phenol imprinted SPR sensor.

Surface homogeneity of phenol imprinted SPR sensor was investigated using adsorption isotherm models (Freundlich, Langmuir and Langmuir-Freundlich models) in Figure 5.

Among the adsorption isotherm models for phenol imprinted SPR sensor, Langmuir has a high regression coefficient $\left(R^{2}=0.9951, \Delta R_{\max }=10.55\right)$, indicating that their binding to phenol imprinted SPR sensor is monolayer (Table 2).

\section{Selectivity studies}

The most important feature of molecular imprinting is the formation of cavities belonging to the template mo- lecule on the polymer surface [45]. The catechol molecule was used as a competitive agent to examine the selectivity of phenol imprinted SPR sensor (Figure 6).

The relative selectivity coefficients of phenol imprinted (MIP) sensors to non-imprinted (NIP) sensor for phenol between phenol/catechol were determined 5.81 in Table 3 . The relative selectivity coefficients $\left(k^{\prime}\right)$ for the phenol molecule show that cavities formed in phenol imprinted polymeric film are formed. The imprinting factor showing the imprinting efficiency was recorded as 2.66 and implied that the imprinting process was accomplished successfully (Table 3).

Table 1. Kinetic constants.

\begin{tabular}{cccc}
\hline \multicolumn{2}{c}{ Equilibrium Analysis } & \multicolumn{2}{c}{ Association Kinetic } \\
\hline$\Delta \mathrm{R}_{\max }$ & 19.77 & $\mathrm{k}_{\mathrm{a}^{\prime}} \mathrm{nM}^{-1} \cdot \mathrm{s}^{-1}$ & 0.0026 \\
\hline $\mathrm{K}_{\mathrm{A}^{\prime}} \mathrm{nM}^{-1}$ & 0.18 & $\mathrm{k}_{\mathrm{d}^{\prime}} \mathrm{s}^{-1}$ & 0.0011 \\
\hline $\mathrm{K}_{\mathrm{D}^{\prime}} \mathrm{nM}$ & 5.35 & $\mathrm{~K}_{\mathrm{A}^{\prime}}, \mathrm{nM}^{-1}$ & 2.36 \\
\hline $\mathrm{R}^{2}$ & 0.9991 & $\mathrm{~K}_{\mathrm{D}^{\prime}} \mathrm{nM}$ & 0.42 \\
\hline & & $\mathrm{R}^{2}$ & 0.9886 \\
\hline
\end{tabular}



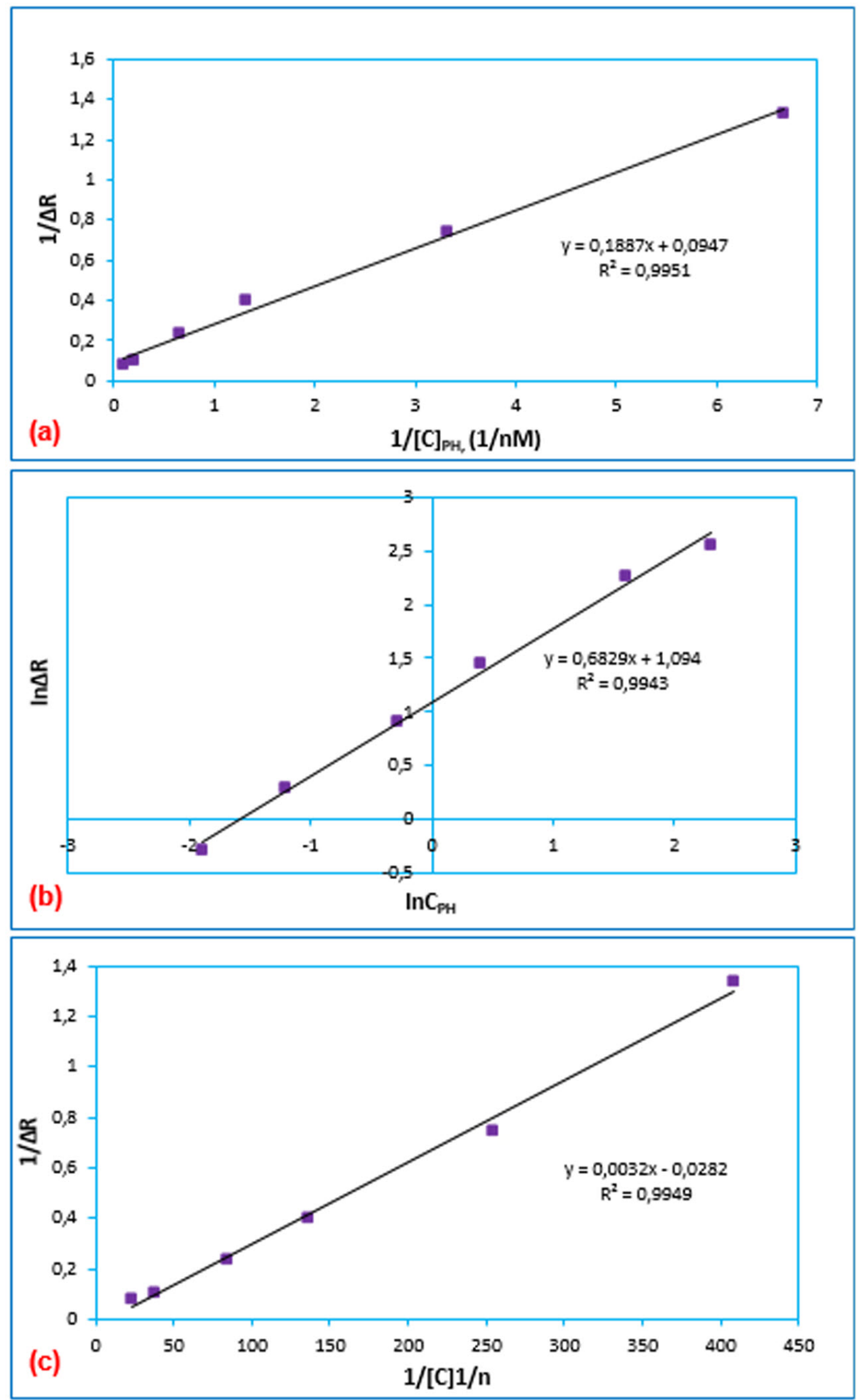

Figure 5. Adsorption isotherm models (a: Langmuir, b: Freundlich, c: Langmuir-Freundlich). 
340 A. Derazshamshir / Hacettepe J. Biol. \& Chem., 2021, 49 (4), 333-344

Table 2. The adsorption isotherm model constants.

\begin{tabular}{|c|c|c|c|c|c|}
\hline \multicolumn{2}{|c|}{ Langmuir } & \multicolumn{2}{|c|}{ Freundlich } & \multicolumn{2}{|c|}{ Langmuir-Freundlich } \\
\hline$\Delta \mathrm{R}_{\max }$ & 10.55 & $\Delta R_{\max }$ & 2.99 & $\Delta R_{\max }$ & 35.46 \\
\hline$K_{D}$ & 1.9926 & $1 / n$ & 0.6829 & $1 / n$ & 0.6829 \\
\hline $\mathrm{K}_{\mathrm{A}}$ & 0.5018 & $\mathrm{R}^{2}$ & 0.9943 & $K_{D}$ & 0.1134 \\
\hline \multirow[t]{2}{*}{$\mathrm{R}^{2}$} & 0.9951 & & & $\mathrm{~K}_{\mathrm{A}}$ & 8.81 \\
\hline & & & & $\mathrm{R}^{2}$ & 0.9949 \\
\hline
\end{tabular}
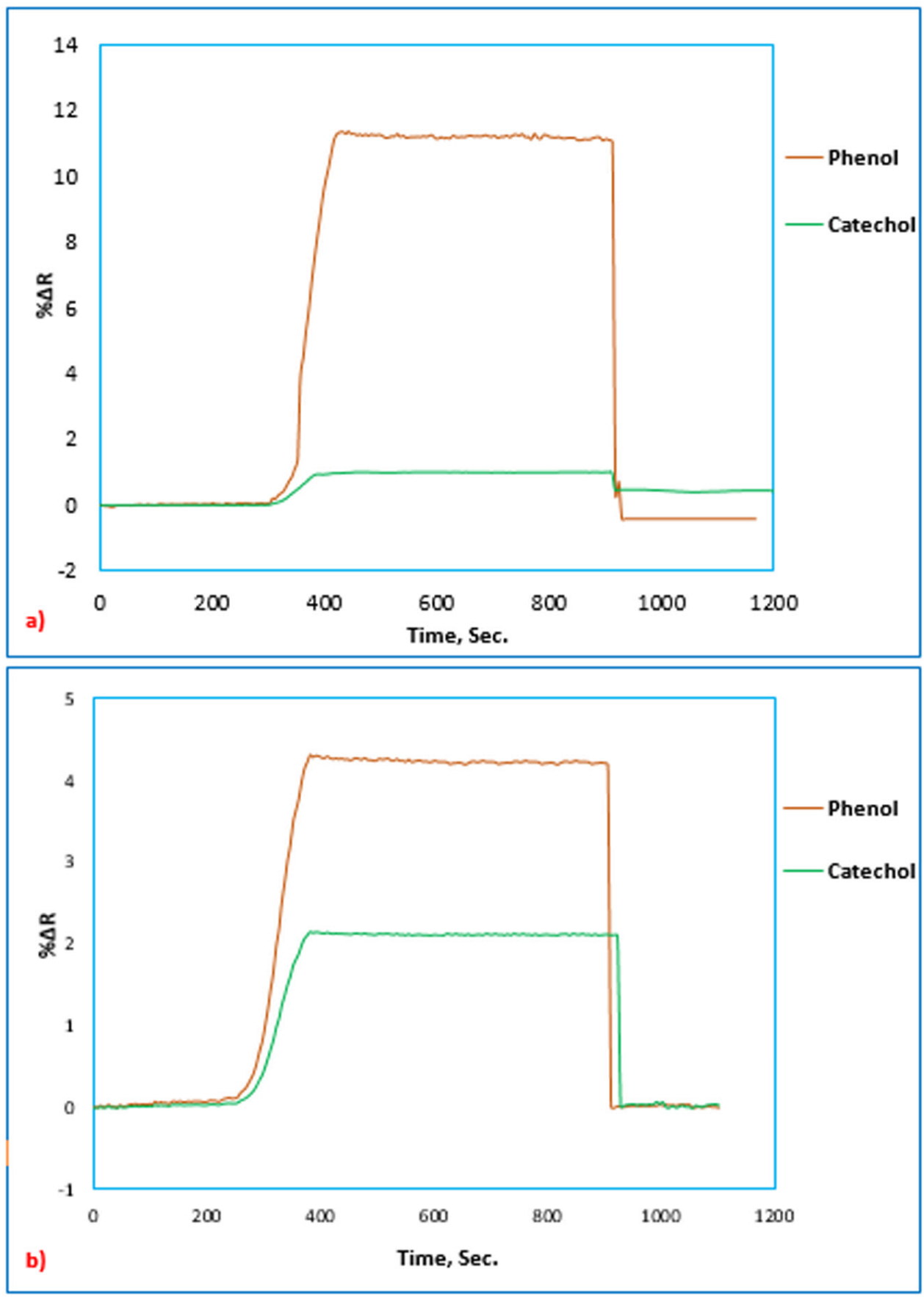

Figure 6. The selectivity studies of phenol imprinted (A) and non-imprinted (B) SPR sensors. 
Table 3. The selectivity and relative selectivity coefficients for competitive molecule for phenol imprinted and non-imprinted SPR sensors.

\begin{tabular}{|c|c|c|c|c|c|}
\hline \multicolumn{3}{|c|}{$\begin{array}{l}\text { Imprinted } \\
\text { Sensor }\end{array}$} & \multicolumn{3}{|c|}{$\begin{array}{l}\text { Non-imprinted } \\
\text { Sensor }\end{array}$} \\
\hline & $\Delta R$ & k & $\Delta R$ & k & $k^{\prime}$ \\
\hline Phenol & 11.19 & - & 4.20 & - & - \\
\hline Catechol & 0.972 & 11.51 & 2.12 & 1.98 & 5.81 \\
\hline
\end{tabular}

\section{Reusability studies}

The reusability studies of phenol imprinted SPR sensor were carried out with four repetitive equilibration-adsorption-regeneration cycles using aqueous phenol solutions. Four cycles were performed by preparing a phenol solution at a concentration of $10 \mathrm{nM}$. According to the four equilibration-adsorption-regeneration cycles analysis results, it has been observed that there is not much decrease in chip performance. SPR sensograms obtained from four repetitive equilibration-adsorptionregeneration cycles are shown in Figure 7.

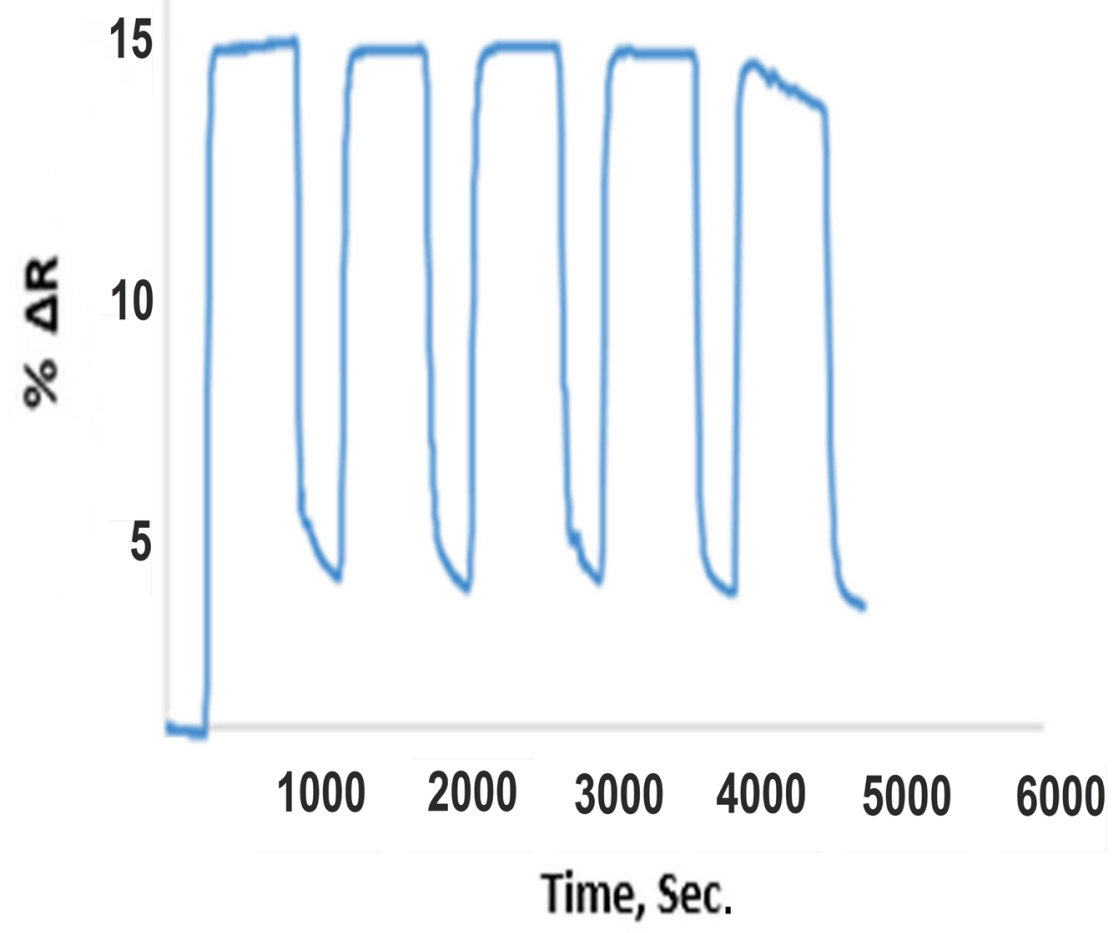

Figure 7. Reusability studies of phenol imprinted SPR sensors. 


\section{Conclusion}

In recent studies, the different methods have been developed for the real time, sensitive and fast, identification tools for phenol and phenol derivatives in industrial wastewater. Optical sensors are used in detecting contaminants due to their low cost, sensitivity, real-time measurement and no labeling required. For the creation of selective recognition regions in surface plasmon resonance sensors, easy to prepare, cheaper, stable, molecularly imprinted polymers with molecular recognition capability are frequently used. Several sensor studies performed in the literature for phenol determination are summarized as follows. Manan et al. [47] prepared tyrosinase biosensors based on quantum dots with nanocrystalline cellulose for phenol determination. Under optimal conditions, the limit of detection was found to be $0.082 \mu \mathrm{M}$ in the phenol concentration range of 5-40 $\mu \mathrm{M}$. In addition, the sensitivity of the prepared biosensor is $0.078 \mu \mathrm{A} / \mu \mathrm{M}$. Both the prepared biosensors and HPLC method, real lake water samples spiked at different concentrations were also analyzed When the results obtained with both methods were compared, it was observed that the results were compatible with each other. Caetano et al. [48] have developed an electrochemical biosensor for phenol detection with a microfluidic device. Screen printed electrodes were modified with gold nanoparticles/carbon nanotubes and covalently bonded as tyrosinase. After the prepared electrochemical biosensors with the cyclic voltammetry technique were characterized, $\mathrm{pH}$, linear range and sensing potential parameters were optimized. The limit of detection and limit of quantification were found to be $2.94 \mathrm{nmol} / \mathrm{L}$ and $8.92 \mathrm{nmol} / \mathrm{L}$, respectively. Aliabadi et al. [49] prepared a composite electrochemical sensor containing cetyl trimethyl ammonium bromide (CTAB) and zincon made from electro-polymerization with cyclic voltammetry for phenol detection in the waste water. The composite electrochemical sensor has been observed to have a linear relationship with a correlation coefficient of 0.992 in the phenol concentration range of 1 to $30 \mathrm{ppm}$. The limit of detection is calculated as 214 ppb. Hashim et al. [50] prepared gold modified tyrosinase (Tyr) enzyme-based graphene oxide (GO) thin film on surface plasmon resonance (SPR) sensor surface for phenol detection. The thin film prepared was characterized by using atomic force microscopy (AFM). Sensitivity, full width at maximum half, detection accuracy and signal-to-noise ratio were analyzed with the SPR sensor. The SPR sensor has been studied in a phenol concentration range of $1 \mu \mathrm{M}$ to $100 \mu \mathrm{M}$ with a sensitivity of 0.00098 . Jesila et al. [51] developed an electrochemical sensor for the determination of 4-Cyanophenol in environmental water using bismuth molybdate $\left(\mathrm{Bi}_{2} \mathrm{MoO}_{6}\right)$ with an Aurivillius-structure. Phenol analyzes were performed in two linear concentration ranges, 0.1-39.1 $\mu \mathrm{M}$ and 46.6-110.1 $\mu \mathrm{M}$, using a $\mathrm{Bi}_{2} \mathrm{MoO}_{6}$ modified glassy carbon electrode. The detection limit for both linear range was $0.008297 \mu \mathrm{M}$ and $0.01097 \mu \mathrm{M}$, respectively. The environmental water sample was also analyzed by both the modified electrochemical sensor and HPLC analysis. The results compared with both methods are analyzed as a real sample with proper and quantification results.

In this study, phenol imprinted SPR sensor was prepared by combining the advantages of molecular imprinting method for the selective and fast determination of phenol molecule. The characterization studies of phenol imprinted and non-imprinted SPR sensors are performed with contact angle and ellipsometer measurements. Then, kinetic studies are carried out in the concentration range of $0.15-10 \mathrm{nM}$. The limit of detection is obtained as $0.022 \mathrm{nM}$. According to the kinetic analysis results, it was determined that Langmuir isotherm model, one of the adsorption isotherm models, is suitable for the phenol imprinted SPR sensor. In addition, in the selectivity studies of phenol SPR sensors, it has been shown that the specific cavities formed on the SPR sensor surface recognize the phenol molecules with higher selectivity than the catechol molecule. In the light of the experimental results, it has been observed that the selectivity of the phenol imprinted SPR sensor can be detected in the low detection limits of phenol compounds. 


\section{References}

1. H. Zhang, L. Yang, B. Zhou, X. Wang, G. Liu, W. Liu, P. Wang, Investigation of biological cell-protein interactions using SPR sensor through laser scanning confocal imaging-surface plasmon resonance system, Spectrochim. Acta. A. Mol. Biomol. Spectrosc., 121 (2014) 381-386.

2. J. Buijs, G.C. Franklin, SPR-MS in functional proteomics, Brief. Funct. Genomic. Proteomic., 4 (2005) 39-47.

3. W.M. Mullett, E.P. Lai, J.M. Yeung, Surface plasmon resonance-based immunoassays, Methods., 22 (2000) 7791.

4. G. Krishnamoorthy, E.T. Carlen, A. Van Der Berg, R.B.M Schasfoort, Surface plasmon resonance imaging based multiplex biosensor: integration of biomolecular screening detection and kinetics estimation, Sensor. Actuators B, 148 (2010) 511-521.

5. A.S. Kushwaha, A. Kumar, R. Kumar, and S.K. Srivastava, A study of surface plasmon resonance (SPR) based biosensor with improved sensitivity, Photonics Nanostruct., 31 (2018) 99-106.

6. S. Zeng, D. Baillargeat, H.P. Ho, and K.T. Yong, Nanomaterials enhanced surface plasmon resonance for biological and chemical sensing applications, Chem. Soc. Rev., 43 (2014) 3426-3452.

7. J.F. Masson, Portable and field-deployed surface plasmon resonance and plasmonic sensors, Analyst, 145 (2020) 3776

8. W.M.E.M.M. Daniyal, Y.W. Fen, N.I.M. Fauzi, H.S. Hashim, N.S.M. Ramdzan, N.A.S. Omar, Recent Advances in Surface Plasmon Resonance Optical Sensors for Potential Application in Environmental Monitoring, Sens. Mater., 32 (2020) 4191-4200.

9. F.R. Caetano, E.A. Carneiro, D. Agustini, L.C.S. FigueiredoFilho, C.E. Banks, M.F. Bergamini, L.H. Marcolino-Junior, Combination of electrochemical biosensor and textile threads: A microfluidic device for phenol determination in tap water, Biosens. Bioelectron., 99 (2018) 382-388.

10. H. Li, C. Han, Sonochemical Synthesis of CyclodextrinCoated Quantum Dots for Optical Detection of Pollutant Phenols in Water, Chem. Mater., 20 (2008) 6053-6059.

11. L. Wu, X. Lu, Dhanjai, Z. Wu, Y. Dong, X. Wang, S. Zheng, J. Chen, 2D transition metal carbide MXene as a robust biosensing platform for enzyme immobilization and ultrasensitive detection of phenol, Biosens. Bioelectron., 107 (2018) 69-75.

12. X.H. Zhou, L.H. Liu, X. Bai, H.C. Shi, A reduced graphene oxide based biosensor for high-sensitive detection of phenols in water samples, Sens. Actuators B Chem., (2013) 661-667.

13. L. Lu, L. Zhang, X. Zhang, S. Huan, G. Shen, R. Yu, A novel tyrosinase biosensor based on hydroxyapatite-chitosan nanocomposite for the detection of phenolic compounds, Anal. Chim. Acta, 665 (2010) 146-151.

14. E. Bazrafshan, F.K. Mostafapour, H.J. Mansourian, Phenolic compounds: health effects and its removal from aqueous environments by low cost adsorbents, Health Scope., 2 (2013) 65-66

15. U.S. Environmental Protection Agency Toxicological Review Phenol. In: Support of summary information on integrated risk information system (IRIS), CAS No. 108-95-2: 104. 2002.

16. C.L. Dang, Y. Lin, Detection of phenol by defective inorganic BN nanosheet: A DFT study, Inorg. Chem. Commun., 117 (2020) 107977.
17. X.D. Lv, P. Gao, An optical sensor for selective detection of phenol via double cross-linker precipitation polymerization, RSC Adv, 10 (2020) 25402-25407.

18. A. Puszkarewicz, J. Kaleta, D. Papciak, Adsorption of phenol from water on Natural Minerals, Ecol. Eng., 19 (2018) 132138.

19. M.H. Aliabadi, N. Esmaeili, H.S. Jahromi, An electrochemical composite sensor for phenol detection in waste water, Appl. Nanosci., 10 (2020) 597-609.

20. R. Wahab, F. khan, N. Ahmad, M. Alam, J. Ahmad, A.A. AlKhedhairy, Rapid sensing response for phenol with $\mathrm{CuO}$ nanoparticles, colloids and surfaces a-physicochemical and engineering aspects, Colloids Surf. A 607 (2020) 125424.

21. C.A. Arenal, B.E. Sample, Chapter 29:Wildlife toxicity assessment for phenol. In: Wildlife toxicity assessments for chemicals of military concern. Elsevier; 2015. p. 555-579.

22. IARC, International Agency for Research on Cancer Phenol. In: IARC Monographs on the evaluation of the carcinogenic risk of chemicals to humans, World Health Organization, 47 (1989) 263-287.

23. G.F. Abu-Alsoud, C.S. Bottaro, Porous thin-film molecularly imprinted polymer device for simultaneous determination of phenol, alkylphenol and chlorophenol compounds in water, Talanta 223 (2021) 121727.

24. R. M. Kamel, A. Shahat, Z.M. Anwar, H.A. El-Kady, E.M. Kilany, Efficient dual sensor of alternate nanomaterials for sensitive and rapid monitoring of ultratrace phenols in sea water, J. Mol. Liq., 297 (2020) 111798.

25. Y. Zhang, L. Qin, Y. Cui, W. Liu, X. Liu, Y. Yang, A hydrophilic surface molecularly imprinted polymer on a spherical porous carbon support for selective phenol removal from coking wastewater, New Carbon Mater., 35 (2020) 220-231.

26. H. Setiyanto, S. Rahmadhani, S. Sukandar, V. Saraswaty, M.A. Zulfikar, N. Mufti, The performance of molecularly imprinted polymers (MIPs)-modified carbon paste electrode and its application in detecting phenol, Int. J. Electrochem. Sci., 15 (2020) 5477-5486.

27. A. Gubin, P. Sukhanov, A. Kushnir, K. Shikhaliev, M. Potapov, E. Kovaleva, Monitoring of phenols in natural waters and bottom sediments: preconcentration on a magnetic sorbent, GC-MS analysis, and weather observations, Chem. Pap., 75 (2021) 1445-1456.

28. L. Qi, R. Liang, W. Qin, Stimulus-responsive imprinted polymer-based potentiometric sensor for reversible Detection of neutral phenols, Anal. Chem., 92 (2020) 42844291.

29. A. Rico-Yuste, S. Carrasco, Molecularly imprinted polymerbased hybrid materials for the development of optical sensors, Polymer, 11 (2019) 1173.

30. C. Alexander, H.S. Andersson, L.I. Andersson, R.J. Ansell, N. Kirsch, I.A. Nicholls, J. O'Mahony, M.J. Whitcombe, Molecular imprinting science and technology: a survey of the literature for the years up to and including 2003, J. Mol. Recognit., 19 (2006) 106-180.

31. J.E. Lofgreen, G.A. Ozin, Controlling morphology and porosity to improve performance of molecularly imprinted sol-gel silica, Chem. Soc. Rev., 43 (2014) 911-933.

32. O.K. Castell, D.A. Barrow, A.R. Kamarudin, C.J. Allender, Current practices for describing the performance of molecularly imprinted polymers can be misleading and may be hampering the development of the field, J. Mol. Recognit., 24 (2011) 1115-1122. 
33. L. Chen, S. Xu, J. Li, Recent advances in molecular imprinting technology: current status, challenges and highlighted applications, Chem. Soc. Rev., 40 (2011) 2922-2942.

34. R. Schirhagl, Bioapplications for molecularly imprinted polymers, Anal. Chem., 86 (2013) 250-261.

35. X. Zhou, W. Li, X. He, L. Chen, Recent advances in the study of protein imprinting, Sep. Purif. Rev., 36 (2007) 257-283.

36. R. Schirhagl, Bioapplications for Molecularly Imprinted Polymers, Anal. Chem., 86 (2013) 250-261

37. S. Li, S. Cao, M. J. Whitcombe, S.A. Piletsky, Size matters: Challenges in imprinting macromolecules, Prog. Polym. Sci., 39 (2014) 145-163.

38. L. Chen, X. Wang, W. Lu, X. Wua, J. Lia, Molecular imprinting: perspectives and applications, Chem. Soc. Rev. 45 (2016) 2137.

39. M. Fizir, A. Richa, H. He, S. Touil, M. Brada, L. Fizir, A mini review on molecularly imprinted polymer based halloysite nanotubes composites: innovative materials for analytical and environmental applications, Rev. Environ. Sci. Biotechnol., 19 (2020) 241-258.

40. Ş. Öncel, L. Uzun, B. Garipcan, A. Denizli, Synthesis of phenylalanine-containing hydrophobic beads for lysozyme adsorption, Ind. Eng. Chem. Res., 44 (2005)7049-7056.

41. A. Derazshamshir, I. Göktürk, E. Tamahkar, F. Yılmaz, N. Sağlam, A. Denizli, Phenol removal from wastewater by surface imprinted bacterial cellulose nanofibres, Environ. Technol., 41 (2020) 3134-3145.

42. V. Safran, I. Göktürk, A. Derazshamshir, F. Yılmaz, N. Sağlam, A. Denizli, Rapid sensing of $\mathrm{Cu}^{+2}$ in water and biological samples by sensitive molecularly imprinted based plasmonic biosensor, Microchem. J., 148 (2019) 141-150.

43. U. Beker, B. Ganbold, H. Dertli, D.D. Gülbayir, Adsorption of phenol by activated carbon: Influence of activation methods and solution pH, Energy Convers. Manag., 51 (2010) 235-240.
44. R.J. Umpleby, S.C. Baxter, Y. Chen, R.N. Shah, K.D. Shimizu, Characterization of molecularly imprinted polymers with the langmuir-freundlich isotherm, Anal. Chem., 73 (2001) 4584-4591.

45. N. Bereli, D. Çimen, S. Hüseynli, A Denizli, Detection of amoxicillin residues in egg extract with a molecularly imprinted polymer on gold microchip using surface plasmon resonance and quartz crystal microbalance methods, J. Food Sci., 85 (2020) 4152-4160.

46. Y. Saylan, F. Yılmaz, A. Derazshamshir, E. Yılmaz, A. Denizli, Synthesis of hydrophobic nanoparticles for real-time lysozyme detection using surface plasmon resonance sensor, J. Mol. Recognit., 30 (2017) e2631.

47. F.A.A. Manan, W.W. Hong, J. Abdullah, N.A. Yusof, I. Ahmad, Nanocrystalline cellulose decorated quantum dots based tyrosinase biosensor for phenol determination, Mater. Sci. Eng. C, 99 (2019) 37-46.

48. F.R. Caetano, E.A. Carneiro, D. Agustini, L.C.S. FigueiredoFilho, C.E. Banks, M.F. Bergamin, L.H. Marcolino-Junior, Combination of electrochemical biosensor and textile threads: A microfluidic device for phenol determination in tap water, Biosens. Bioelectron., 99 (2018) 382-388.

49. M.H. Aliabadi, N. Esmaeili, H.S. Jahromi, An electrochemical composite sensor for phenol detection in waste water, Appl. Nanosci., 10 (2020) 597-609.

50. H.S. Hashim, Y.W. Fen, N.A.S. Omar, J. Abdullah, W.M.E.M.M. Daniyal, S. Saleviter, Detection of phenol by incorporation of gold modified-enzyme based graphene oxide thin film with surface plasmon resonance technique, Opt. Express, 28 (2020) 9738-9752.

51. J.A. Jesila, N.M. Umesh, S.F. Wang, G. Mani, A.A. Alothman, R.A. Alshgari, An electrochemical sensing of phenolic derivative 4-Cyanophenol in environmental water using a facile-constructed Aurivillius-structured $\mathrm{Bi}_{2} \mathrm{MoO}_{6}$, Ecotoxicol. Environ. Saf., 208 (2021) 111701. 